\title{
DIETARY BEHAVIOUR IN STUDENTS WITH DIFFERENT BODY FAT PERCENT
}

\author{
Rudīte Lagzdina, Leons Blumfelds, Maija Rumaka, and Līga Aberberga-Augškalne \\ Department of Human Physiology and Biochemistry, Rīga Stradinšs University, Dzirciema iela 16, Rīga LV-1007, LATVIA
}

Communicated by Ingrīda Rumba

\begin{abstract}
Eating habits with uniform food preferences and increased energy intake can contribute to increased gain of body fat. An adequate diet, body self-evaluation, and recognition of unhealthy nutrition patterns should promote appropriate corrective actions. The aim of the present study was to determine whether energy intake, food diversity and corrective modification of body mass differed among student groups with low, normal and high body fat percentage. The study involved 737 (158 male and 579 female) students of the Riga Stradinš University (age 18-49 years). Dietary behaviour was determined using self-administered questionnaire. Body fat percentage was determined with a Tanita MC-180 bioimpedance analyser. Fluid and food intake, as well as physical activity before the test was restricted. The results showed that $15 \%$ of students in the low, $38 \%$ in the normal and $62 \%$ in the high body fat percentage groups considered that they eat too much. In the low, normal and high body fat percentage groups of students, $27 \%, 37 \%$ and $42 \%$, respectively, agreed that they do restrict food intake. There were no significant differences in normalised energy intake and food diversity indexes between these student groups. Students in the high body fat percentage group more frequently admitted eating to much, and their corrective behaviour was associated more with reduced amounts of eaten food rather than minimisation of energy intake and increased food diversity. In all fat percentage groups, female students more frequently admitted that they eat too much and more often tended to restrict food intake than male students.
\end{abstract}

Key words: body fat percent, eating habits, energy intake, food diversity.

\section{INTRODUCTION}

Incidence of obesity, especially in children and young adults, is increasing. This indicates a the need to determine the main causal factors and to advise on effective prevention (Chizuru, 2004). The adiposity in this age can predispone persons to diabetes mellitus, cardiovascular diseases, degenerative joint diseases, certain cancers and other health risks in further life (Anonymous, 2000). Energy balance of energy intake and energy expenditure enables to maintain normal body weight.

Nowadays energy intake is influenced by high availability of energy dense food, rich with fat and added sugars, while intake of complex carbohydrates, dietary fibers, as well as fruits and vegetables is reduced (Anonymous, 2003). This situation stimulates increased energy intake, but energy expenditure is markedly decreased due to low physical activity.

In such conditions the natural body weight regulation mechanisms in some cases are not able to provide effective body weight control, and therefore the importance of conscious activities to maintain normal body size is increased
(Lowe, 2003). Eating habits with uniform food preferences and increased energy intake can contribute to increased gain of body fat. An adequate diet, body self-evaluation, as well as recognition of unhealthy nutrition patterns, can promote appropriate corrective activity. Adoption of healthy dietary behaviour is an effective way to maintain normal body weight and composition (Roach et al., 2003).

The aim of the present study was to determine whether energy intake, food diversity and body mass corrective modification differ among students within low, normal and high body fat percentage groups.

\section{MATERIALS AND METHODS}

All students who were residents of Latvia and who attended a physiology course in Rịga Stradiňš University from 2009-2012 were invited to participate in the investigation. The investigation involved 737 (158 male and 579 female) students of the Rìga Stradiňš University with age 18-49 years. Persons were involved voluntarily and the investigation was conducted according to the requirements of Ethical Committee of the Rịga Stradiņš University. 
At onset all of the students were asked to identify their eating habits by completing a self-administered questionnaire. The questionnaire consisted of 64 questions examining eating style, food diversity and product preferences. In the questionnaire, groups of questions were selected that characterise energy intake and food diversity. The acquired score in each group of questions was expressed as energy intake index and food diversity index, respectively. Higher energy index indicates a tendency to consume products with higher caloric values. Higher food diversity index is associated with using a diet with higher variety of products, including fibre-rich and low-energy dense food.

Then, body height of participants was measured to the closest $0.1 \mathrm{~cm}$ using a standard wall-mounted height measuring device. Body weight to the closest $0.05 \mathrm{~kg}$ and fat percentage with accuracy $0.1 \%$ were estimated using a multifrequency body composition analyser MC-180MA (Tanita, Japan). To obtain more precise results, fluid and food intake, as well as physical activity level of the participants before the test were limited. Students with metal implants and pregnant female students were excluded from the investigation. Body fat percentage was evaluated according to the predicted values (Gallagher et al., 2000) (Table 1). The students were divided into three groups - low fat $\%$, normal fat $\%$ and high fat $\%$.

Table 1

CHARACTERISTICS OF THE STUDIED POPULATION (mean \pm SD)

\begin{tabular}{lcc}
\hline \multicolumn{1}{c}{ Parameter } & Males & Females \\
\hline Age (years) & $20.8 \pm 3.0$ & $21.3 \pm 3.7$ \\
Height $(\mathrm{cm})$ & $181.8 \pm 7.2$ & $168.7 \pm 5.7$ \\
Weight $(\mathrm{kg})$ & $75.4 \pm 10.8$ & $61.3 \pm 10.1$ \\
Fat percent $(\%)$ & $14.4 \pm 5.7$ & $24.7 \pm 5.8$
\end{tabular}

The obtained data were analysed using SPSS software version 17.0 (SPSS Inc., Chicago). Alpha level $P<0.05$ was considered as statistically significant. Differences in distributions between both genders were evaluated using a Chi square test.

\section{RESULTS}

Of the studied population, $75 \%$ males and $67 \%$ females had a normal fat percentage. $10 \%$ males and $25 \%$ females had a low fat percentage, and $15 \%$ males and $8 \%$ females had an increased fat percent (Figs. 1 and 2)

The frequency distributions of yes or no answers to the statement „In my opinion I eat too much” differed significantly between student groups with low, normal and high fat percentages. According to the questionnaire, 52\% males and $67 \%$ females with high fat percentage thought that they eat too much. In the group of students with normal fat percent this answer was given by $17 \%$ males and significantly more $(45 \%)$ females $(P<0.05$ for gender differences). Surprisingly, also $6 \%$ males and $16 \%$ females in the group of students with a low fat percentage thought that they eat too much (Fig. 3).

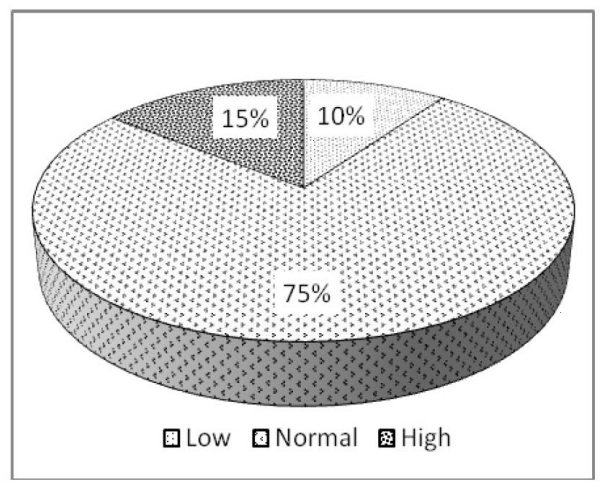

Fig. 1. Frequencies of low, normal and high fat percentage among males.
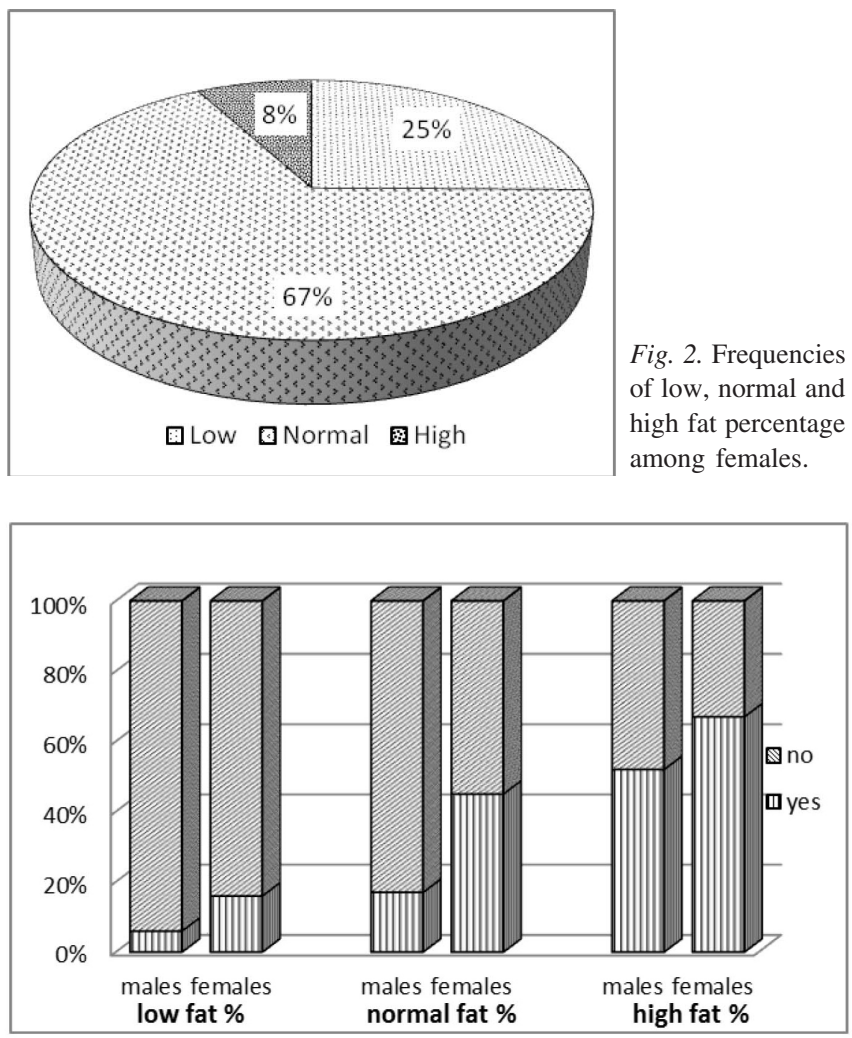

Fig. 3. Percentage of males and females in the low, normal and high fat percent groups, who answered yes or no to the statement „In my opinion I eat too much"

Significant $(P<0.05)$ difference between low, normal and high fat percent groups according to the Chi square test.

Statistically significant differences were observed between the groups of low, normal and high fat percentage groups according to the answers in the statement "I restrict my food amount". $33 \%$ males and $47 \%$ females with a high fat percentage agreed that they restrict their food amount. In the group of students with normal fat percentage only $27 \%$ males and $40 \%$ females agreed. Even $30 \%$ of females with a low body fat percentage agreed that they restrict their food amount (Fig. 4).

On average most of the students were in the low or medium tertile of energy intake index. There were no statistically significant differences in index of energy intake between males and females with different fat percentages. However, the energy intake index of females with normal and high fat percentages was lower than in males $(P<0.05)$ (Fig. 5). 


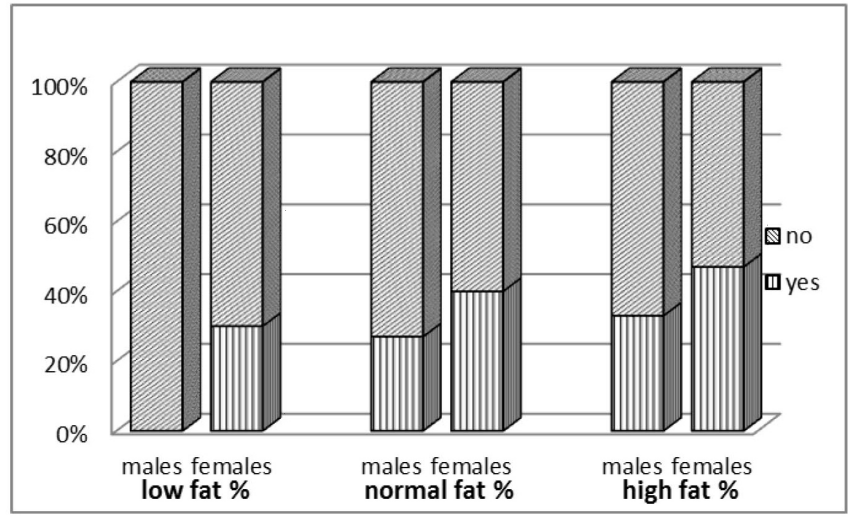

Fig. 4. Percentage of males and females in the low, normal and high fat percentage groups who answered yes or no to the statement „I restrict my food amount".

Significant $(P<0.05)$ difference between low, normal and high fat percent groups according to the Chi square test.

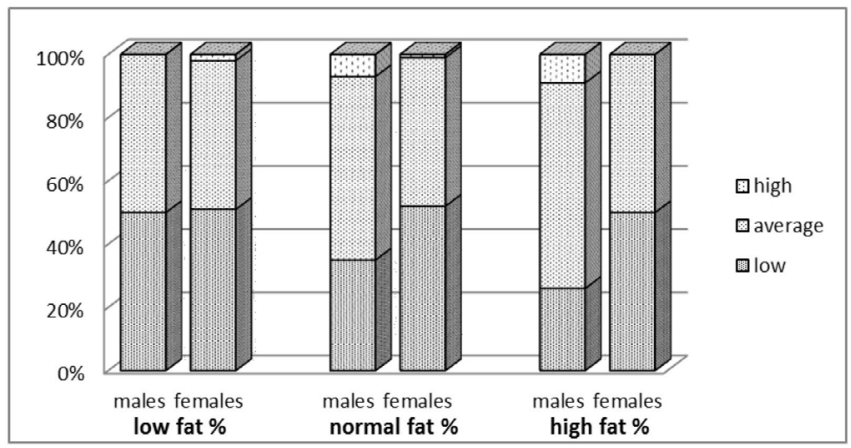

Fig. 5. Percentage of males and females in low, normal and high fat percentage groups according the tertile of energy intake index.

No significant $(P>0.05)$ difference between low, normal and high fat percent groups according to the Chi square test; significant $(P<0.05)$ difference between males and females in normal and high fat percent groups according to the Chi square test.

Generally, most of the students were in the high or medium tertile of food diversity index. Distribution of students in the three tertiles among groups of low, normal and high fat percentage groups was quite similar. No significant differences in distribution of this index were observed between males and females in any of these groups (Fig. 6).

\section{DISCUSSION}

The average fat percentage of students involved in the study was normal. In this, as well as in previous studies (Blumfelds et al., 2008), females prevailed in the group of low fat percentage, while males in the group of high fat percentage. These data are consistent with other reports about young adults (Mohsen, 2007); however, they show higher rates of overweight and obese men than in our study.

It is known that females are more exposed to eating disorders such as anorexia nervosa and bulimia nervosa (Hilbert et al., 2012). However, binge eating disorder and subthreshold binge eating disorder is more common in males than females (Hudson et al., 2007; Sepulveda et al., 2008).

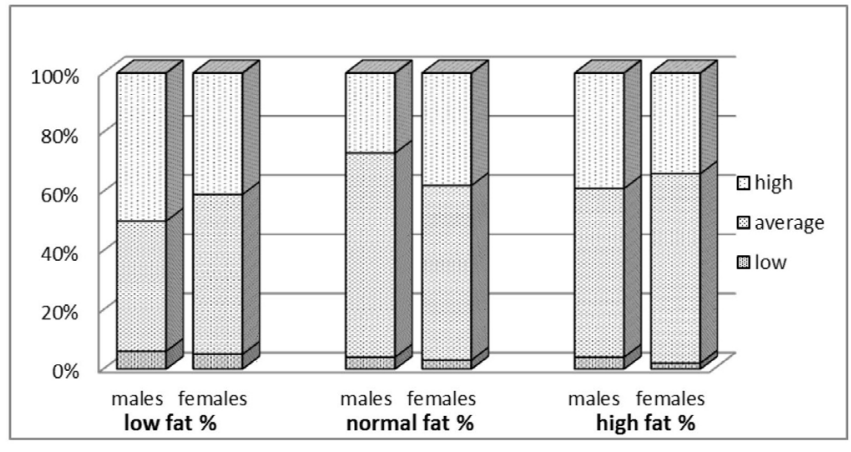

Fig. 6. Percentage of males and females in low, normal and high fat percent groups according the tertile of food diversity index.

No significant $(P>0.05)$ difference between low, normal and high fat percent groups according the Chi square test.

The ability to evaluate one's own body size is important when weight management activities are initiated. The self-evaluation of body size is not very accurate, especially when the body mass index (BMI) and fat percent are below or above normal range. Persons with higher BMI and fat percentage tend to underestimate their BMI, and persons with lower BMI overestimate it (Blumfelds et al., 2011). In another study involving students from 22 countries in which, body mass index was used to characterise the weight/height relationship, a steady increase in perceived overweight with increase of BMI decile was observed (Wardle et al., 2006).

A low body fat percentage might be the indication of engagement in sports and fitness (Hetland et al., 1995; 1998) or impending, or borderline eating disorder (Probst et al., 1996). Students with a low fat percent who answered that they are overeating most probably could be linked with the latter.

It is not surprising that people with a high fat percentage chose restriction of food intake as the first activity for body weight control. The higher the fat percent, the higher is the urge to implement some corrective activities in one's life. In studies of the general population of the USA and Germany, it was found that females restrict their food intake more than males (Striegel-Moore et al., 2009). Young women are pursuing extremely low ideal body weight and are risking their mental and physical health. They more frequently perceive themselves overweight and engage in different weight control activities that are irrational and even hazardous (Crawford and Owen, 1994; Patton et al., 1997; Wardle et al., 2006). A total of 44 to $81 \%$ of USA college females with normal and increased BMI, respectively, report consciously eating less than they want to promote their weight loss. This dietary behaviour, similar to that in our study, was more frequent in groups of overweight and obese females (Malinauskas et al., 2006).

Students who considered some corrections of body weight, more often tended to decrease the amount of food eaten and thus caloric intake rather than increasing product diversity. Females have been observed to be more concerned about their diet than males, in our and also in other studies 
(Mikulan et al., 2012). In people with a borderline high body fat percentage, a decrease of amount of food eaten may be effective to normalise body weight, in persons with a high fat percent it may be ineffective by only decreasing intake of products with high caloric value, if these are not substituted with alternatives with lower energy density (Prentice and Jebb, 2003).

The lack of significant differences in energy intake index across low, normal and high fat percentage groups in this study most probably could be related to composition of the questions used for the index analysis. This study did not consider weight of each separate question used in the questionnaire and each question was not studied specifically.

In conclusion, students in the high fat percentage group more frequently admitted eating to much, and their corrective behaviour was more associated with restriction of eaten food amount rather than reduction of energy intake and increase of food diversity.

Female students more frequently admitted that they eat too much and tended more to restrict food intake than male students in all fat percentage groups.

\section{REFERENCES}

Anonymous (2000). Obesity: Preventing and managing the global epidemic. Report of a WHO Consultation. WHO Technical Report Series 894. Geneva. 253 pp.

Anonymous (2003). Diet, nutrition and prevention of chronic diseases. Report of a joint WHO/FAO Expert Consultation. WHO Technical Report Series 916. Geneva. 149 pp.

Blumfelds, L., Rumaka, M., Lagzdina, R., Aberberga-Augskalne, L. (2011). Ar svaru saistītās k,ermeņa uzbūves pašnovērtējuma precizitāte studentiem [Accuracy of self-estimated body weight-height relationship in students]. 2011. gada RSU zinātniskās konferences tēzes: 141 (in Latvian).

Blumfelds, L., Aberberga-Augškalne, L., Rumaka, M., Lagzdina, R. (2008). Kermena sastāva komponentu analīze studentiem [Analysis of body compositions components in students]. 2008. gada RSU zinātniskās konferences tēzes: 77 (in Latvian).

Chizuru, N. (2004). Overweight and obesity a new nutrition emergency? SCN News, 29. United Nations Standing Committee on Nutrition. http://www.unscn.org/layout/modules/resources/files/scnnews29.pdf

Crawford, D., Owen, N. (1994). The behavioral epidemiology of weight control. Austr. J. Publ. Health, 18, 143-148.

Gallagher, D., Heymsfield, S. B., Moonseong, H., Jebb, S. A., Murgatroyd, P. R., Sakamoto, Y. (2000). Healthy percentage body fat ranges: An ap- proach for developing guidelines based on body mass index. Amer. J. Clin. Nutr., 72, 694-701.

Hetland, M. L., Haarbo, J., Christiansen, C. (1998). Regional body composition determined by dual X-ray absorptiometry. Relation to training, sex hormones, and serum lipids in male long-distance runners. Scand. J. Med. Sci. Sports, 8 (2), 102-108.

Hetland, M. L., Haarbo, J., Christiansen, C. (1995). Body composition and serum lipids in female runners: Influence of exercise level and menstrual bleeding pattern. Eur. J. Clin. Invest., 25 (8), 553-558.

Hilbert, A., de Zwaan, M., Braehler, E. (2012). How frequent are eating disturbances in the population? Norms of eating disorder examination questionnaire. PLoS ONE, 7 (1): e29125. doi:10.1371/journal.pone.0029125. http://www.plosone.org/article/ info\%3Adoi\%2F10.1371\%2Fjournal.pone.0029125

Hudson, J. I., Hiripi, E., Pope, H. G., Kessler, R. C. (2007). The prevalence and correlates of eating disorders in the National Comorbidity Survey Replication. Biol. Psychiatr., 61, 348-358.

Lowe, M. R. (2003). Self-regulation of energy intake in the prevention and treatment of obesity: Is it feasible? J. Obesity Res., 11, 44S-59S.

Malinauskas, B. M., Raedeke, T. D., Aeby, V. G., Smith, J. L., Dallas, M. B. (2006). Dieting practices, weight perceptions, and body composition: A comparison of normal weight, overweight, and obese college females. Nutr. J., 5, 11.

Mikulan, R., Piko, B. E., (2012). High school student's body weight control: Differences between athletes and non-athletes. Coll. Antropol., 36 (1), 79-86.

Mohsen, M., Obesity and dislipidemia among young general physicians in Iran. (2007). Int. J. Cardiol., 118 (1), 111-112.

Patton, G. C., Carlin, J. B., Shao, Q., Hibbert, M. E., Rosier, M., Selzer, R., Bowes, G. (1997). Adolescent dieting: Healthy weight control or borderline eating disorder? J. Child. Psychol. Psychiatry, 38, 863-880.

Prentice, A. M., Jebb, S. A. (2003). Fast foods, energy density and obesity: A possible mechanistic link. Obesity Rev., 4, 187-194.

Probst, M., Goris, M., Vandereycken, W., Van Coppenolle, H. (1996). Body composition in female anorexia nervosa patients. Brit. J. Nutr., 76 (5), 639-647.

Roach, J. B., Yadrick, M. K., Jonson, J. T., Boudreaux, J. L., Forsythe, W. A., Billon, W. (2003). Using self-efficacy to predict weight loss among young adults. J. Amer. Diet. Assoc., 103, 1357-1359.

Sepulveda, A. R., Carrobles, J. A., Gandarillas, A. M. (2008). Gender, school and academic year differences among Spanish university students at high risk for developing an eating disorder: An epidemiologic study. BMC Public Health, 8, 102.

Striegel-Moore, R. H., Roselli, F., Perrin, N., DeBar, L., Wilson, T. G., May, A., Kraemer, H. C. (2009). Gender difference in the prevalence of eating disorder symptoms. Int. J. Eat. Disord., 42 (5), 471-474.

Wardle, J., Haase, A. M., Steptoe, A. (2006). Body image and weight control in young adults: International comparisons in university students from 22 countrieas. Int. J. Obes., 30, 644-651.

Received 3 September 2012

\section{ĒŠANAS PARADUMI DAŽĀDA VECUMA STUDENTIEM AR DAŽĀDU RELATĪVO ĶERMEN̦A TAUKU DAUDZUMU}

Ěšanas paradumi ar vienveidīga uztura izvēli un pārmērīgu enerğijas uzṇemšanu var veicināt palielinātu ķermeņa tauku uzkrāšanos. Savas diētas un ķ,ermeņa adekvāts pašvērtējums, kā arī neveselīgu ēšanas paradumu atpazǐšana varētu veicināt piemērotu koriǵējošu rīcỉbu. Šī pētījuma mērķis bija noteikt, vai enerğijas uzņemšana, uztura dažādība un ķermeņa masu regulējoša rīcība ir atšķirīga studentu grupās ar zemu, normālu un augstu ķermeņa tauku procentu. Pētījumā brīvprātīgi tika iesaistīti 737 (158 vīrieši un 579 sievietes) Rīgas Stradiņa universitātes studenti vecumā no 18 līdz 49 gadiem. Uztura paradumu pētīšanai tika lietota anketa, ko studenti aizpildīja patstāvīgi. Kermeņa tauku daudzums dalībniekiem tika izmērìts ar bioimpedances analizatoru Tanita MC-180. Pirms mērījuma studentiem tika noteikti šķidruma, uztura uzņemšanas un fiziskās aktivitātes ierobežojumi. Rezultāti parādīja, ka 15\% studentu zema, 38\% normāla un 62\% augsta ķermeņa tauku procentu grupā uzskata, ka viņi èd par daudz. Attiecīgi — zema, normāla un augsta ķermeņa tauku procentu grupā — $27 \%, 37 \%$ un $42 \%$ studentu piekrita apgalvojumam, ka viņi ierobežo savu uztura daudzumu. Normalizētie enerğijas uzņemšanas un uztura daudzveidības indeksi būtiski neatškīrās studentiem ar dažādu relatīvo k̦ermeņa tauku daudzumu. Studenti augsta k̦ermeņa tauku procentu grupā biežāk nekā pārējie uzskatīja, ka viṇi êd par daudz, un viņu koriğèjošā rīcība galvenokārt bija saistīta ar uzṇemtā uztura daudzuma ierobežošanu, nevis uzṇemtās enerğijas apjoma samazināšanu un uztura daudzveidības palielināšanu. Visās kermen,a tauku procentu grupās sievietes biežāk nekā vīrieši atzina, ka èd par daudz un cenšas ierobežot savu uztura daudzumu. 